\title{
Commercial bakers' views on the meaning of "local" wheat and flour in western Washington State
}

\author{
Karen M. Hills, ${ }^{a}$ Jessica R. Goldberger, ${ }^{\mathrm{b}}{ }^{*}$ and Stephen S. Jones ${ }^{\mathrm{a}}$ \\ Washington State University
}

Submitted February 22, 2013 / Revised April 23, 2013 / Accepted May 13, 2013 / Published online September 17, 2013

Citation: Hills, K. M., Goldberger, J. R., \& Jones, S. J. (2013). Commercial bakers' views on the meaning of "local" wheat and flour in western Washington State. Journal of Agriculture, Food Systems, and Community Development, 3(4), 13-32. http://dx.doi.org/10.5304/jafscd.2013.034.022

Copyright (C) 2013 by New Leaf Associates, Inc.

\begin{abstract}
Most existing efforts toward revitalizing local food production have focused on fresh produce and animal products, largely neglecting staple crops such as grains. Nevertheless, there has been increasing interest in many parts of the United States in relocalizing grain production. Wheat is the most commonly consumed grain in the United States. Commercial bakers could be important supplychain intermediaries for locally grown wheat, but little is known about their attitudes toward local wheat and how they define local. We surveyed commercial bakers in western Washington State and interviewed experts involved with local wheat movements in other regions. Thirty-four percent of survey respondents defined local as within the state

a Northwestern Washington Research and Extension Center, Washington State University, Mount Vernon, Washington 98273 USA.

b Department of Crop and Soil Sciences, Washington State University, Pullman, Washington 99164 USA.

* Corresponding author: Jessica Goldberger; +1-509-335-8540; jgoldberger@wsu.edu
\end{abstract}

of Washington, 25 percent provided a multistate definition, and 14 percent provided a flexible (or reflexive) definition that referred to two or more geographic regions. Perceived barriers to purchasing local wheat included supply-chain, price, quality, and scale factors. We conclude with discussion of the opportunities and challenges for the relocalization of wheat flour supply chains.

\section{Keywords}

commercial bakers, local food, relocalization, short supply chains, Washington State, wheat

\section{Introduction and Literature Review}

In recent years, local food systems have received renewed attention in the academic literature (Bloom \& Hinrichs, 2010; Ostrom, 2006; Peters, Bills, Lembo, Wilkins, \& Fick, 2009), the popular press (Kingsolver, Hopp, \& Kingsolver, 2007; Pollan, 2006), and government initiatives such as the U.S. Department of Agriculture's “Know Your Farmer, Know Your Food" program (USDA, n.d.). The local food movement was born out of the environmental movement with concerns about 
"food miles" and the long-distance transport of food (Pirog \& Rasmussen, 2008); the community food security movement with concerns about access to healthy, affordable food (Feenstra, 1997); and as a response to the conventionalization of organic agriculture (Fonte, 2008). The local food movement emphasizes supporting local farmers and encouraging consumers to understand the origin of their food (Ilbery \& Maye, 2005). The benefits attributed to local food fall into several categories: economic (e.g., jobs in production, processing, and distribution), environmental (e.g., decreased food miles), and social (e.g., increased accountability of agricultural enterprises to local communities).

While various authors have sought to define local foods (Dunne, Chambers, Giombolini, \& Schlegel, 2010; Giovannucci, Barham, \& Pirog, 2010; Ostrom, 2006; Pirog \& Rasmussen, 2008; Selfa \& Qazi, 2005), there is a shortage of literature on how "local" is defined in the context of staple crops such as wheat. This study aims to better understand the definition of local wheat from the perspective of commercial bakers, who are important supply-chain intermediaries. Through a mail survey of commercial bakers in western Washington, our goal was to learn how commercial bakers define local in the context of purchasing wheat and flour for their bakeries, and to understand what they perceive as barriers to the purchase of local wheat. In addition, we conducted telephone interviews with three knowledgeable individuals involved in wheat relocalization in other parts of the U.S. to add perspectives from other regions. While our survey results may not be generalizable to other areas, they can inform grain relocalization efforts by revealing the inherent challenges and opportunities in connecting staple crop (e.g., wheat) producers, supply-chain intermediaries (e.g., processors and bakers), and consumers. In addition, our study contributes to the nascent literatures on the relocalization of staple crops and the perspectives of supply-chain intermediaries.

\section{Definition of Local}

Local is one of many attributes that can be attached to a food product to communicate value to consumers. For these attributes to be trusted by consumers, it is helpful to have agreed-upon definitions. The concept of local food has been criticized for its lack of a firm definition (DeLind, 2011; Ostrom, 2006; Schnell, 2013; Tregear, 2011). Third-party certifiers do not set the definition nor regulate the use of the term "local" on U.S. food product labels. Some popular definitions that have been proposed include those based on political boundaries (e.g., within a particular state), distance (e.g., 100 miles [161 km]), or bioregion (Martinez et al., 2010). Pirog and Rasmussen (2008) found that most consumers in the West (13-state region) considered local to be within a 100-mile (161-km) radius. In the 2008 Food, Conservation, and Energy Act, the U.S. Congress defined the total distance that a product can be transported and still be considered a locally or regionally produced agricultural food product as "less than 400 miles [644 km] from its origin, or within the state in which it is produced." In a study of food retailers' definition of local, Dunne et al. (2010) found that definitions of local varied widely and were neither strict nor tightly regulated. Further discussion of the definition of local can be found in Giovannucci et al. (2010) and Martinez et al. (2010).

\section{Complicating Factors in the Definition of Local}

Local food has inherent complexities that make it difficult to define the term. In the case of plantbased foods, definitions of "local" may depend on whether the crop is grown in one's region, and on the existence of infrastructure and supply chains to make the identity-preserved local crop available. What qualifies as local for one type of food crop may not be the same for another type of food crop. For example, a consumer in Washington may consider California avocados to be local, but expect that apples advertised as local come from within the state or even within the county.

The idea of "flexible" or "reflexive" localism was introduced by Morris and Buller (2003) and refers to an elastic definition of local depending on the ability to source supplies within a short distance or further away (Ilbery and Maye, 2006). Flexible localism can also exist in terms of producers marketing products. Drawing on Washington survey data, Qazi and Selfa (2005) found that 66 percent of producers in heavily populated King 
County, compared with 20 percent of producers in sparsely populated Grant County, defined their local market to be their own or surrounding counties.

Flexible localism implies that the emphasis on local food provisioning is a means to an end, rather than an end in itself. Ilbery and Maye (2006) note that flexible localism reflects the inherent complexities of food systems and acknowledge that the distinction between local/alternative and global/ conventional may obscure the hybrid nature of many food supply chains that involve both local and global food products. Embeddedness - the goal of local - has more to do with community, economy, and social relations resulting from the food system than with a set definition based on factors such as political boundaries or distance.

When local foods are expanded beyond whole foods and into processed and multi-ingredient products, the idea of local is further complicated. What percentage of the ingredients must be local for the product to be considered local? Is local based on where products are grown (or raised) or where they are processed? Even more questions arise when considering the involvement of multinational corporations in marketing of local food. Frito-Lay advertised the use of local ingredients in the states where the company sources potatoes for Lay's potato chips (Severson, 2009). Walmart is reaching out to local farm suppliers to satisfy customer demand for local produce (Cantrell \& Lewis, 2010). To the most dedicated believers, supporting locally grown food is "part of a broad philosophical viewpoint that eschews large farming operations, the heavy use of chemicals and raising animals in confined areas" (Severson, 2009, p. D1). Often part of this viewpoint includes keeping dollars in the local economy by supporting locally owned stores rather than multinational corporations.

\section{Grains as Local Food}

Much of the attention in local food systems has been focused on produce and animal products, with very little attention paid to staple crops such as grains. Staple crops are those crops that provide a majority of calories in human diets and are also critical as livestock feed. Wheat is one of the most important staple crops, providing 19 percent of human calories worldwide (Mitchell \& Mielke, 2005). Wheat is the world's largest crop by production area and second largest crop by quantity produced (USDA-Foreign Agricultural Service, 2011). In 2009, U.S. annual per capita consumption of wheat flour products was $134 \mathrm{lb}(61 \mathrm{~kg})$, or 69 percent of total flour and cereal products (USDAEconomic Research Service, 2009), making wheat the most important staple crop in the United States.

Wheat is considered a "commodity crop," meaning that it is essentially interchangeable on the market. The price paid to the grower is determined by a board of exchange, which represents "one of the largest, most impersonal of systems shaping our relationship to food. Although it is almost completely divorced from real grain, its influence is seen well beyond the trading floor — on the farm and in the grocery store, and all over the world" (Kavage, n.d., "The Details: The Point," para. 1). Movements aimed at food system reform have problematized food's treatment as a simple commodity and have called for "decommodifying food” (McClintock, 2010).

Commodity agriculture, which involves the production of staple crops such as wheat, corn, and soybeans, is often viewed as antithetical to sustainable agriculture by sustainable agriculture advocates (Lyson, 2004). The system of commodity agriculture is often blamed for the abundance of cheap processed food in the U.S. and the epidemics of obesity and diabetes (Carolan, 2011). Food deserts are defined, in part, by a shortage of fresh fruits and vegetables (Ver Ploeg et al., 2009) rather than by a shortage of wheat-based carbohydrates (though it could be argued that most food deserts have a shortage of whole-grain options). Despite these issues, staple crops such as wheat still play an important role in food systems in general and sustainable agricultural systems as food, feed, and malt.

Grains are fundamentally different from the produce and animal products that currently dominate the local food market. Wheat shares many qualities with other grains and staple crops and thus many of the same issues in terms of its place in a local food system. Over the past two genera- 
tions, consolidation within the grain industry has resulted in a dismantling of grain production and processing infrastructure in many communities that once produced much of their own grain (Hefferman, Hendrickson, \& Gronski, 1999; Hergescheimer \& Wittman, 2012; Hills, Corbin, \& Jones, 2011). With concern about food security and the vulnerabilities inherent in our modern food system (Hanus, 2010), staple crops such as wheat may play an increasingly important role in relocalization efforts, as communities attempt to reestablish the infrastructure necessary for local food systems. The relocalization movement attempts to extend sustainability to the entire supply chain, including processing, packaging, and transport (Fonte, 2008).

The perspectives of producers and consumers have been a popular subject of study in research on local food systems, but the importance of supplychain intermediaries is a topic that has been less frequently explored in the literature on local food systems. A better understanding of the perspectives of supply-chain intermediaries has the potential to reveal the barriers and opportunities for connecting consumers with local food resources (Dunne et al., 2010; Feenstra, 1997). A USDA study that analyzed 2008 Agricultural Research Marketing Service data found that most sales of local food occur through intermediated marketing channels such as regional distributors and grocery stores, restaurants, and other local retailers (Low \& Vogel, 2011). In 2008, at least 60 percent of the value of local foods reached consumers through intermediated channels (distributor, grocery, restaurant) (Low \& Vogel, 2011).

Existing literature on the perspectives of supply-chain intermediaries includes several studies of direct sales to restaurants, schools, and other institutions. In a USDA rural development report, Painter (2008) reviews existing farm-to-school programs and farmer-chef collaboratives as methods for marketing differentiated farm products. Starr, Card, Bnepe, Auld, Lamm, Smith, and Wilken (2003) examine the connections between local (produce) farmers and restaurants and institutions in Colorado. Inwood, Sharp, Moore, and Stinner (2009) look at the characteristics of early adopters, motivations for using local foods, and barriers to adoption of local food use by Ohio chefs. Vogt and Kaiser (2008) found in their review of 19 studies of farm-to-institution and farm-to-school linkages that institutional support was needed to transition to this method of purchasing. This literature points to lack of infrastructure and financial support for processing and central distribution as the most important barriers in the creation of local food connections. As with most literature on local food, these papers do not mention local grain.

Despite the lack of literature in relation to local food systems, supply-chain intermediaries are especially important with a food such as wheat, which typically involves more processing, blending, and other intermediary activities than many other foods. A key difference in local grain systems (as opposed to commodity markets) is that generally the identity of the grain is preserved through processing and distribution, so that information about who grew the grain and where it was grown is available to the consumer. While wheat is an ingredient in many different products, much of the anecdotal interest on the purchasing side of local wheat has involved small-scale, artisan bakers (Hills et al., 2011).

\section{Bakers as Potentially Important Intermediaries in Local Wheat Value Chains}

Since the 1970s there has been growing interest in a return to "artisan" bread made without stabilizers, dough conditioners, and preservatives (Suas, 2009). Artisan baking has come to stand for a "commitment to production methods that employ traditional skills distinct from the highly controlled and automated production systems of the factory bakery" (Bassetti \& Galton, 1998, p. 20). Rather than sharing a shape, ingredients, or style, artisan breads' common element is that they were "touched by the hand, assessed by the eye and subject to the baker's judgment at every step" (Bassetti \& Galton, 1998, p. 20). John Yamin, CEO of La Brea Bakery (a bakery chain based in southern California), estimates that artisan bread accounts for 13 percent of the bread market measured in dollars. He attributes this to a greater awareness among customers of the quality of the food they consume (Whitaker, 2007). 
Commercial and artisanal bakers are the focus of our project because they have the potential to get locally grown wheat to the consumer while preserving the "story" of the wheat. Commercial bakers have a unique perspective on the possibilities of using local wheat because of their position in the supply chain between processors and consumers. They are also closer than their customers to the wheat and, consequently, may have a greater interest in the wheat's origin. A bakery consultant at Great Harvest Franchising, Inc. (Dillon, Montana), said consumers are increasingly looking for locally produced baked products made from sustainable products (Thilmany, 2010).

While extensive literature exists on the definition of local food (see, e.g., Dunne et al., 2010; Givoanucci et al., 2010; Pirog \& Rasmussen, 2008), there is a lack of available research on what local means with respect to staple crops such as wheat and how it is defined by commercial bakers, who are important supply-chain intermediaries in the case of wheat and flour. One exception to this is a study of social relations among organic cereal and bread producers, processors, and marketers in Austria, in which Milestad, Bartel-Kratochvil, Leitner, and Axmann (2010) described a pragmatic definition of local based on the availability of products locally and the location of potential consumers. It was not clear whether these results would be relevant for western Washington or other regions of the U.S. and across organic and conventional supply chains. We aim to address this gap in the literature with the research outlined below, which focuses on the definition of local by commercial bakers in western Washington State.

\section{Western Washington}

In 2008, Washington produced US\$745 million worth of wheat (Brady and Taylor, 2011), 85 percent of which is exported internationally (Washington Grain Alliance, 2010). The Cascade Mountains divide the state into two distinct bioregions, with the majority of the wheat produced in the eastern part of the state and the majority of the population residing in the western part. Eastern Washington has some of the greatest production of commodity wheat in the nation, produced for an export-driven market and moved through a well- established network facilitating the transport of commodity wheat. While western Washington is more commonly known for the production of horticultural crops such as berries, tulips, and vegetables, wheat is an important rotation crop grown to improve soil quality and break disease cycles. Its value as a rotation crop makes wheat worth growing, even if growers do not profit from the wheat. This wheat is usually sold on the commodity market and offers growers very little return; usually the grower is trying to "lose less money" on the wheat crop. This lack of profit is due to the smaller scale of the farms and the higher land values in western compared to eastern Washington, as well as the lack of support programs (e.g., subsidies), which are more available to their larger counterparts in eastern Washington. Because vegetable processors have largely left the area, western Washington growers are left with fewer options for their crop rotation, making it more important for each part of the rotation, including wheat, to generate profit. These growers have used vertical integration and identity preservation to maintain their economic competitiveness in other markets (e.g., potatoes, bulbs, berries). Thus, selling their wheat to nearby metropolitan areas where consumers are concerned with local food and farmland preservation is of great interest to growers (Patzek, 2012). Developing a market for local wheat would benefit growers and make the wheat component of the rotation more profitable.

Low and Vogel (2011) found that proximity to a metropolitan area, access to farmers' markets and farmland, and location in the coastal regions of the U.S. are drivers of direct-to-consumer sales. This suggests that local food sales have the greatest potential for economic development in specific places and regions of the country. Skagit County in northwestern Washington had over US\$2.5 million in direct-to-consumer sales of farm products in 2007 and is part of a trend of local food production in the Pacific Northwest concentrated in the areas of higher population density, west of the Cascade Mountains. Western Washington has a higher population density than eastern Washington, and has over 424,000 acres (171,586 hectares) acres of farmland (USDA-National Agricultural Statistics Service, 2007). Grains are grown in 
rotation with other crops on some western Washington farmland. The density of farmers' markets, which could be used as a proxy for interest in local foods, is quite high west of the Cascade Mountains (see figure 1).

Western Washington is one of many areas of the country where movements are underway aimed at bringing back the local production of grains for local consumption in areas where they were historically grown and processed (Hills \& Jones, 2012). Bakers in Victoria, British Columbia; Mount Vernon, Washington; Athens, Ohio; and Asheville, North Carolina, are connecting with growers to reform parts of the supply chain lost over time to consolidation and industrialization of the wheatmilling sector. The goal is often to shorten the supply chain so growers can receive more of the final product's market share (Appalachian Staple Food Cooperative, n.d.; Hanus, 2010; Hergescheimer \& Wittman, 2012; Wolfe, 2011).
Because western Washington is not far from a large area of commodity wheat production and has some of its own production, there are both challenges and opportunities for relocalization of wheat. Some bakers in western Washington are buying Washington-grown wheat from a company called Shepherd's Grain, a group of no-till wheat farmers in eastern Washington who market their wheat, which is milled by Archer Daniels Midland (ADM), as part of a value chain that includes identity preservation on each bag of flour (Stevenson, 2009). This brings up the question of what is "local enough" for bakers and their customers and, in the case of baked goods, for commercial bakers.

Consumers and food-chain intermediaries such as chefs might consider a 100-mile radius as necessary for fruits and vegetables to be considered local; however, it is not clear how perceptions change when considering wheat flour used in a multiingredient product. Food-chain intermediaries

\section{Figure 1. Farmers' Market Locations and Wheat-producing Counties in Washington State}

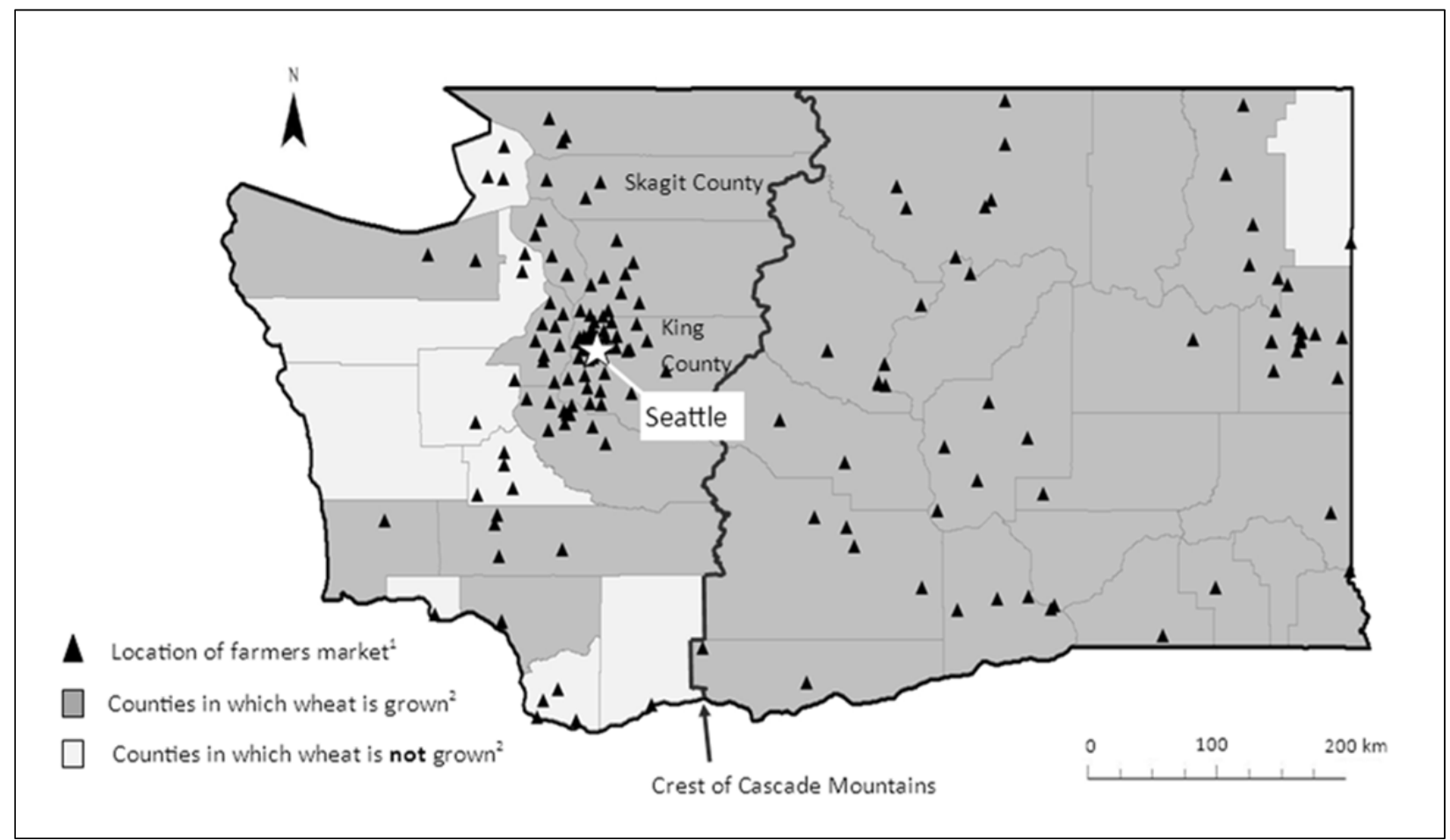

1 J. Sage, personal communication, 2012.

${ }^{2}$ Compendium of Washington Agriculture, 2011.

Figure 1 is from "Commercial Bakers and the Relocalization of Wheat in Western Washington State," by K. M. Hills, J. R. Goldberger, and S. S. Jones, 2013, Agriculture and Human Values, 30(3), 365-378. Copyright 2013 by Springer Science+Business Media B.V. Reprinted with permission. 
represent "control points" of a local food system as decisions they make influence the system (Dunne et al., 2010). Commercial bakers are the intermediary with the most ability to buy local wheat flour in large quantities. Understanding commercial bakers' views of local when it comes to flour purchases will provide new insight into local foods in general and local staple crops in particular.

The overall goal of this project was to better understand the important complexities associated with the relocalization of a wheat/flour system by examining the practices and perspectives of commercial bakers. The primary questions addressed are:

- How do commercial bakers define "local" in relation to purchasing wheat/flour for their bakeries?

- How do commercial bakers' opinions of local wheat/flour compare to their perceptions of their customers' opinions of local wheat/flour?

- What are commercial bakers' perceptions of their customers' willingness to pay a premium for products made with Washington-grown versus westernWashington-grown wheat?

- What do commercial bakers see as barriers to the development of a local wheat system?

To address these questions, we surveyed commercial bakers in western Washington. In addition, we conducted interviews with intermediaries (millers or bakers) involved in newly formed wheat relocalization movements to explore grain relocalization efforts in other parts of the country. While the results of this study may not be generalizable to other regions in the U.S. or worldwide, they can inform wheat relocalization efforts by revealing the complexities as well as the inherent challenges and opportunities in relocalizing staple crops.

\section{Methods}

Survey

Using a modified Tailored Design Method

(Dillman, Smyth, \& Christian, 2009), we sent questionnaires to commercial bakers in the 19 Washington counties west of the Cascade Mountains. Defined as a "foodshed" in a recent publication (American Farmland Trust, 2012), the study region was chosen because the majority of Washington's population and thus the majority of bakeries in the state are concentrated in the western part of the state. Grocery store bakeries and large national chain bakeries were not included in our study because we wanted to target bakeries with a greater ability to adjust processes or try new ingredients. We also excluded bakeries that exclusively sell cakes, cupcakes, doughnuts, and/or pies because we assumed their customers might be less attuned to local foods. Names and addresses of bakeries were obtained through a variety of sources, including the Washington State Department of Agriculture's list of licensed food processors, the King County Public Health Department's list of inspected food service establishments, and an email announcement sent by the Bread Bakers Guild of America to its members. We also searched for the word "bakery" in Google Maps. Several professional bakers outside the survey area were consulted during questionnaire development.

A cover letter and questionnaire were sent to 267 commercial bakers on March 31, 2011. A reminder postcard was sent on April 7, 2011, followed by a final mailing to nonrespondents on April 28, 2011. Individuals responsible for making purchasing decisions for commercial bakeries were instructed to complete the questionnaire. We collected general information on the characteristics of the bakeries, current sourcing of flour, and interest in purchasing flour from western Washington. In other questions, respondents were asked about regionally produced flour. We intentionally left "regionally produced" undefined because we wanted to allow respondents to reflexively define the term rather than rely on a single definition provided by us. Seventy-three eligible bakers responded to the survey (33 percent response rate). We did not contact nonrespondents to find out why they had not participated in the study. However, we found that response rates varied by county. Response rates were 60 percent or greater for five counties (Clallam, Grays Harbor, Island, Pierce, and San Juan) and less than 25 percent for 
three counties (Cowlitz, Jefferson, and King). We did not detect a clear geographic pattern based on county response rate. In addition, we did not discern significant differences between respondents and nonrespondents in terms of business type (based on bakery name). A more in-depth analysis of nonresponse bias would have helped our interpretation of the survey results.

\section{Interviews}

To supplement the information from the survey, we conducted semi-structured interviews with three individuals who have been active in wheat relocalization efforts in the southeastern and northeastern U.S. The interviews took place in June 2012 and were conducted by phone. Interviewee 1 has 39 years of experience in the baking industry. Currently a consultant for a well-known, independently owned mill, he works with commercial bakers and offers technical support and advice to local grain enthusiasts. Interviewee 2 is a commercial baker who operates a bakery with 40 fulltime employees and sources 20 percent of his flour from wheat grown within his state (which is not known for its wheat production). He is familiar with the challenges and benefits of using local wheat in his bakery. Interviewee 3 was a professional baker for 14 years and is now a central figure in her region's effort to revitalize small grain processing and has led a project to open a small mill that provides locally grown wheat to bakers in her area.

\section{Results}

\section{Characteristics of Survey Respondents}

Table 1 presents descriptive statistics for the surveyed bakeries. Of the 73 survey respondents, 45 percent were located within heavily populated King County, which includes Seattle. Eighty-nine percent were bakery owners, 88 percent had only one location, 49 percent employed four or fewer people, 60 percent distributed their products only within their own counties, and 90 percent made at least one-quarter of their sales from direct-toconsumer sales. For 57 percent of respondents, bread sales made up less than 25 percent of their total sales. Annual flour use ranged from $120 \mathrm{lb}$ (54
Table 1. Descriptive Statistics for Surveyed Bakeries

\begin{tabular}{|c|c|c|}
\hline Bakery characteristic & $N$ & Percentage \\
\hline \multicolumn{3}{|l|}{ Location } \\
\hline King County & 33 & 45.2 \\
\hline Other counties & 40 & 54.8 \\
\hline \multicolumn{3}{|l|}{ Part of franchise or chain } \\
\hline Yes & 2 & 2.7 \\
\hline No & 71 & 97.3 \\
\hline \multicolumn{3}{|l|}{ Number of full-time employees } \\
\hline 4 or fewer & 36 & 49.3 \\
\hline $5-10$ & 19 & 26.0 \\
\hline More than 10 & 18 & 24.7 \\
\hline \multicolumn{3}{|l|}{ Sales strategies a } \\
\hline Wholesale & 42 & 60.0 \\
\hline Retail & 59 & 84.3 \\
\hline Cafe or restaurant & 40 & 57.1 \\
\hline \multicolumn{3}{|c|}{ Percentage of sales from direct-to-consumer sales } \\
\hline Less than $25 \%$ & 7 & 10.1 \\
\hline $25-75 \%$ & 14 & 20.3 \\
\hline More than $75 \%$ & 48 & 69.6 \\
\hline \multicolumn{3}{|l|}{ Products sold a } \\
\hline Cookies & 56 & 76.7 \\
\hline Pastries & 51 & 69.9 \\
\hline Bread & 48 & 65.8 \\
\hline Cakes/cupcakes & 45 & 61.6 \\
\hline Pie & 45 & 61.6 \\
\hline Pizza & 11 & 15.1 \\
\hline Doughnuts & 9 & 12.3 \\
\hline Other products & 20 & 27.4 \\
\hline \multicolumn{3}{|l|}{ Percentage of sales from bread } \\
\hline None & 17 & 24.6 \\
\hline Less than $25 \%$ & 22 & 31.9 \\
\hline $25-75 \%$ & 24 & 34.7 \\
\hline More than $75 \%$ & 6 & 8.7 \\
\hline \multicolumn{3}{|l|}{ Product distribution range } \\
\hline Within county & 44 & 60.3 \\
\hline Within neighboring counties & 13 & 17.8 \\
\hline Within Washington & 5 & 6.9 \\
\hline Within Pacific Northwest & 6 & 8.2 \\
\hline Nationally & 5 & 6.9 \\
\hline
\end{tabular}

a Respondents could check more than one answer.

Table 1 is from "Commercial Bakers and the Relocalization of Wheat in Western Washington State," by K. M. Hills, J. R. Goldberger, and S. S. Jones, 2013, Agriculture and Human Values, 30(3), 365-378. Copyright 2013 by Springer Science+ Business Media B.V. Reprinted with permission. 
$\mathrm{kg})$ for a bakery and deli in a rural area to over 1.5 million $\mathrm{lb}$ (over $700,000 \mathrm{~kg}$ ) for a pita bread bakery with national distribution. Only 7 percent of the bakers milled some of their own flour. This flour accounted for only $11,278 \mathrm{lb}(5,116 \mathrm{~kg})$ annually, or 12 percent of total wheat flour used by those bakers owning mills and 0.15 percent of wheat flour used by all respondents.

\section{How Do Commercial Bakers Define "Local"?}

Survey respondents were asked to define local in relation to purchasing flour/wheat for their bakery. Most respondents provided answers based on geopolitical boundaries (state or multistate region) rather than bioregion (e.g., coastal Northwest) or distance (e.g., 100 miles) (table 2). Approximately one-third (34 percent) of respondents defined local as within Washington. Twenty-five percent defined local in terms of a multistate region. Some respondents referenced the "Pacific Northwest" or "western region" without listing specific states,

\section{Table 2. Commercial Bakers' Definitions of "Local" in Relation To Purchasing Wheat/Flour}

\begin{tabular}{|c|c|c|}
\hline Definition of "local" & $\begin{array}{l}\text { Number of } \\
\text { respondents }\end{array}$ & $\begin{array}{l}\text { Percentage of } \\
\text { total sample }\end{array}$ \\
\hline Within Washington & 25 & 34.2 \\
\hline Within multistate regiona & 18 & 24.7 \\
\hline Flexible definition ${ }^{b}$ & 10 & 13.7 \\
\hline Miles or distance ${ }^{c}$ & 6 & 8.2 \\
\hline Within western Washington & 4 & 5.5 \\
\hline Within county & 1 & 1.4 \\
\hline Other definitions ${ }^{d}$ & 3 & 4.1 \\
\hline No definition provided & 6 & 8.2 \\
\hline Total & 73 & 100.0 \\
\hline
\end{tabular}

a These answers referred to the "Pacific Northwest," "western U.S.," or listed two or more specific states or provinces (Washington, Oregon, Idaho, Montana, Wyoming, California, British Columbia).

b These answers included two or more definitions of local, such as: "In-state or incounty," "Vashon Island or WA State," "Within Washington State but mostly within county limits," "San Juan County, primarily; west of the Cascades, secondarily," "Surrounding counties or states," and "Pacific Northwest as a general rule, state centric preferred."

c Answers included 50 miles, 100 miles, 200 miles, 10-hour drive, and 1-day drive.

d Other definitions included: "Can be delivered within a week," "Local distribution," and "I don't know if it is grown local or not unless it says on the bags." while other respondents listed two or more specific states or provinces (mentions included Washington, Oregon, Idaho, Montana, Wyoming, California, and British Columbia). Only seven percent of respondents defined local in terms of a county or multicounty region (i.e., western Washington). Eight percent of respondents provided a distancebased definition of local (e.g., 100 miles or 10-hour drive). Twelve percent of respondents either did not answer the question or provided a definition that did not fit the geopolitical boundary or distance categories.

Fourteen percent of respondents provided a flexible (or reflexive) definition of local (table 2). These respondents mentioned two or more definitions of local, such as: "In-state or in-county," "Vashon Island or WA State," "Surrounding counties or states," and "Western Washington Washington State - Northwest region of U.S." Several respondents who provided flexible definitions indicated a preference for a smaller rather than larger geographic range: "Within Washington State but mostly within county limits," "Pacific Northwest as a general rule, state-centric preferred," "Regional - as local as we can get it," and "Within the western one fourth of the U.S., although I'd love if it came from Washington."

Interviewees were also asked how they defined local with respect to wheat flour. Interviewee 1, a mill consultant, had the following thoughts about the term "local" as it applies to wheat flour and other foods:

What means local for one thing is not necessarily the same as for another. Let's look at quality. Obviously you want a local tomato, local lettuce because there's just a buge difference, you want local fresh eggs. Even if you don't think of the economy and the social structure, even if all you're looking at is end product, local is good when you talk fruits, vegetables, eggs, but with grain it's kind of hard. The wheat that I mill today that I bought from western Kansas is going to be in 
every bit as good a condition as wheat that I got today that was grown [nearby]. There's no quality difference because it's local. So I think that local bakers, manufacturers, and their customers have to be convinced for other reasons that it's important for them to support local small grain agriculture.

Here, the mill consultant recognizes that supporters of local grains may tend to have reasons based on societal benefits (e.g., environmental benefits and local economic development) rather than individual benefits (e.g., personal health and freshness).

Interviewee 2, a commercial baker who has gone to considerable effort to work with farmers to source 20 percent of his wheat from within his state, remarked:

If we're calling something local, the agreed upon definition in this area is within 100 miles of wherever it's being consumed. I can accept that. I don't adhere rigidly in my own diet or not even close to that in our purchases at the bakery - it would be unrealistic. But I do think it would be dishonest marketing to market wheat flour as local if it was milled by a local miller but with wheat grown further away.

Interviewee 2 sees differences between sourcing local flour and other local products:

\section{It's interesting with wheat and wheat flour because wheat flour is produced in such large quantities all over the world that we don't even really value it anymore. I sometimes refer to it as the canvas, upon which we as bakers do our work. And I don't mean to minimize it by saying that. It's just that unbleached wheat flour, while it is extremely important, it gets transformed significantly in the baking process so it's not the same as getting a plate of local beef at a restaurant where it's really easy to connect the farmer to the meal you have in front of you.}

Interviewee 2 also acknowledged some of the complexities involved in labeling a product as local. After developing a recipe specifically featuring local wheat, including packaging that stated it was made from 100 percent in-state-grown wheat, a poor growing season resulted in a limited supply of wheat from one of the two growers supplying the bakery. The bread ended up being made with 85 percent in-state-grown wheat. The baker had to change the label to adjust to the change in wheat origin.

These complexities in the definition of local illustrate reasons why bakers may adopt a flexible definition of local that reflects regionally relevant factors such as the availability of products.

\section{Relationship Between Bakery Characteristics and Bakers' Definition of Local}

We conducted cross tabulations and chi-square tests (available upon request) to examine the relationships between selected bakery characteristics and bakers' definition of local. We found no statistically significant relationships between definitions of local and the following bakery characteristics: bakery size (number of employees), percentage of total sales from direct-to-consumer sales, percentage of sales from bread, geographic distribution of bakery products, or sales strategies (i.e., wholesale, retail, café/restaurant). We did find, however, a statistically significant relationship between distribution area of a bakery and the baker's definition of local. Bakeries distributing only within their county were more likely to include a larger area in their definition of local than those who distributed in areas outside their own counties. Though the reasons for this are not clear, it may be that bakeries that distribute only within their counties are more aware of the limitations on sourcing local ingredients.

\section{Importance of Wheat Origin to Commercial Bakers and Their Customers}

To begin to understand bakers' awareness of and interest in wheat origin, we asked bakers if they were currently purchasing any Washington-grown wheat/flour. Approximately one-third (32 percent) of survey respondents were purchasing Washington-grown wheat/flour (mostly Shepherd's Grain from eastern Washington), 47 percent were not, and 21 percent did not know the origin of their wheat/flour. We then asked bakers if they were interested in purchasing flour made from wheat 
grown in western Washington. Sixty-one percent of respondents were interested in western Washington wheat/flour, 3 percent were not interested, and 36 percent did not know if they were interested. Chi-square analysis indicates no statistically significant relationship between current purchasing of Washington-grown wheat/flour and bakers' definition of local. However, we find a slight relationship (chi-square $=7.891 ; p=0.096$ ) between interest in purchasing western Washington wheat/flour and bakers' definition of local. Commercial bakers who defined local in terms of western Washington and those who provided a flexible definition of local were more interested in purchasing flour made from western Washington wheat compared to bakers who defined local in other ways.

We also asked bakers about the importance of wheat origin for their bakery products, as well as their perceptions of the importance of wheat origin for their customers. The level of importance was measured on a scale from 1, "not important," to 5, "very important." Over one quarter (26 percent) of bakers felt wheat origin was "very important" (with a mean score of 3.6 on the scale of importance). Only 10 percent of bakers perceived that their customers feel wheat origin is "very important" (with a mean score of 2.9 on the scale of importance). Fifty-five percent of survey respondents scored the importance of wheat origin higher for themselves than their customers, while 38 percent scored the importance equally. Increasing demand by bakery customers for products made from local wheat could convince bakers to take the extra steps to source wheat from a closer geographic region (e.g., Washington or western Washington).

We asked commercial bakers to rate the importance (on a scale from 1, "not important," to 5 , "very important") of certain factors in their future purchases of regionally produced flour. The mean scores for "where the wheat was grown" and "where the flour was milled" were 3.6 and 3.4, respectively (Hills et al., 2013). We found that bakers who place a greater importance on where wheat is grown were more likely to be already purchasing Washington wheat/flour $(p=0.003)$, while bakers who place a greater importance on where wheat is milled also expressed a greater interest in purchasing flour made from wheat grown in western Washington $(p=0.013)$.

\section{Bakers' Perceptions of Customers' Willingness To Pay Price Premiums}

When asked whether their customers would be willing to pay a price premium for products made with wheat grown in Washington, 34 percent of survey respondents answered yes, 24 percent answered no, and 42 percent did not know. When the same question was asked about products made from wheat grown in western Washington, 17 percent answered yes, 28 percent answered no, and 55 percent did not know. Of the respondents who said their customers would be willing to pay a premium for products made from Washington wheat, 52 percent did not know if their customers would be willing to pay a premium for products made from western Washington wheat. These results suggest a greater level of uncertainty regarding consumer interest in products made from western Washington wheat versus Washington wheat, possibly because of the lack of an established supply chain for western Washington wheat.

\section{Perceived Barriers To Purchasing Regionally Produced Wheat}

Overall, there was some uncertainty about sourcing wheat/flour from western Washington, which is not surprising because the supply-chain infrastructure to connect local growers to local consumers has been dismantled over the past two generations and has not yet been fully replaced. Moreover, wheat grown in the area is often overshadowed by crops more easily recognized by the public, such as tulips, vegetables, and berries. Survey respondents and interviewees were asked to elaborate on barriers (or potential barriers) to the purchase of wheat/flour from their region. Understanding market intermediaries' perceived barriers is an important way to advance local food systems. The majority of comments focused on four main areas: supply chain, price, quality, and scale (each of which is described in more detail below). Though some aspects of the survey and interviews are specific to western Washington and the locations of the interviewees, we believe these topics have 
relevance for people in other areas working to relocalize grain production.

\section{Supply chain}

Many survey respondents mentioned the lack of an existing supply chain for western Washington wheat and the importance of using existing distributors that are able to source identity-preserved flour. The processing of wheat usually involves some degree of blending wheat from different farms to achieve desired end-use qualities, a step that makes identity preservation uncommon in standard flour supply chains. Survey respondents' comments reflected these challenges:

Not really "knowing" where wheat was grown. Having to keep tabs on my suppliers - it's hard enough keeping tabs on my staff.

Unfamiliar territory of where to purchase small quantities of [all-purpose] flour.

I would use it almost exclusively if I could get a stable supply.

It's hard to find local products that my distributor carries.

A barrier in the supply chain identified by bakers was the lack of processing equipment in western Washington for the most commonly used flour in bakeries: white flour. One baker stated that unbleached white flour constituted 90 percent of his bakery's flour usage and he needed sifted stoneground or roller-milled flour. The existing organic mill sourcing from local growers offers hammermilled whole-wheat flour and does not sift out bran. White flour is usually produced using a roller mill, a much more expensive piece of equipment that produces a more consistent particle size than either a stone or hammer mill. Though many bakers have whole-grain offerings, the majority of flour used by the survey respondents was white.

\section{Price}

Price was a concern mentioned by 38 percent of survey respondents. Because the existing infrastructure for processing wheat in western
Washington consists of a relatively small organic mill and several small mills housed in bakeries, the limited amount of flour available commercially from western Washington is relatively expensive, with a $2 \mathrm{lb}(0.9 \mathrm{~kg})$ bag selling in some cases for $\$ 4.00$ or more. Faced with the prospect of paying these prices, which were more than eight times higher than commercial flour prices, it is likely that commercial bakers would not be interested. The redevelopment of infrastructure around grain processing in western Washington would help to drive the price of flour down through economy of scale. However, it is unclear what the price would be at various levels of production or if the bakers (and hence their customers) would be willing to pay premiums for local wheat. One baker in western Washington who was interviewed prior to our survey said that his customers' threshold was paying 25 percent more for a loaf of bread if it was made from local wheat. A survey respondent described economic concerns well:

\section{Volume of use for us would be limited to a function of price - there are only so many customers willing to pay extra for local. Unable to convert to all local at a premium price, can farmers make a margin selling direct to mill (vs. commodity), so miller and distribution rates bring flour at market rates or close?}

Scale of production and processing as well as the farmers' expectation for return affect the price charged for local flour. Interviewee 1 commented on price issues:

It's so much more expensive to buy the locally milled, locally grown flour than it is to buy something, even an organic something, [grown] in the middle of the country. Part of it is cost of production, part of it is that the growers seem to think they ought to get the same per acre on wheat as they did for tobacco, which is not going to happen, or as they do for carrots or whatever their other cash crops are. I think that's a real issue. It's fine if you're selling flour at the farmers' market, but if you're trying to sell to a bakery they will say "T have to pay you three times as much for 
this stuff?" How much of a premium can the bakery ask?

Interviewee 2 said of local flour: "The prices are very close at this point. Even though there are just a few farmers in [my state] doing their own thing, they are actually quite tied to the global wheat market. If nothing else, just because their prices need to match what people are generally paying for flour." He also said that with both farmers (one using his own stone mill and one contracting with a local roller mill): "We're paying roughly the same per bag of flour as we are for flour coming out of Kansas. The farmers are getting more and the truckers are getting less because they're not going nearly as far."

Interviewee 3 discussed price as one of the drivers for the mill she opened. In 2008 the price of flour spiked 130 percent. Bakers were having enough trouble with availability and quality of their standard flour sources to be willing to take a risk by using local wheat. She said: "We came into this not just to get cheap flour for bakers, but to figure out how we can create real pricing: the best possible price to the grower at an affordable cost to the baker, something that would enable them both to thrive." The motivation for the mill was, in part, to create a more equitable system where pricing is determined by the growers and the bakers involved, rather than by the global commodity market.

\section{Quality}

One part of the survey asked bakers to rate the importance of various factors for future purchases of regionally produced flour. Of the 18 factors listed, flour quality and consistency of flour quality were rated as the most important (Hills et al., 2013). A significant amount of effort goes into developing a formulation used in a bakery. If a new batch of flour does not perform as expected, there is potential for wasted time and product. Commercial bakers have come to expect the consistency between batches of flour they purchase, much like consumers have come to expect a high level of consistency in the products they purchase in the supermarket.
This sentiment was supported in comments made by the survey respondents:

The flour would have to perform consistently. If the flour was priced well and available all the time and most importantly delivers the same results every time I would give it a try.

\section{We have tried other local flours but we feel they} don't work as well as the one we already use.

Quality is the [number one] priority, along with consistency. Lack of equipment for processing in [western W ashington] leads to problems.

The main concern would be the ability of farmers to have a consistent crop every year.

These comments point to the importance of the miller in the wheat supply chain. The miller's role involves quality control and blending to achieve a consistent product.

Scale

Recent literature on local food systems has focused on the "scaling up" of these systems beyond farmers' markets and farm-to-institution initiatives to penetrate the mainstream food market. As noted by King, Gómez, and DiGiacomo (2010), mainstream markets such as supermarkets use a huband-spoke distribution system that allows for extremely efficient movement across great distance. These distribution systems favor large-scale suppliers who can reliably provide large quantities of products, which can be difficult for many producers of local food to provide. Local food may be a better fit for midscale distributors who may have more flexibility in sourcing from local suppliers.

The importance of efficient processing and distribution systems was highlighted by Interviewee 2 , in comparing his two sources of local flour:

For the flour that comes from [the local roller mill] and is milled from wheat grown on [one of our supplying farms], it goes right into [the warehouse] and comes on a truck right to us, which in my opinion is just how it should be done, if we're going to ramp it up in terms of quantity... And that to 
me speaks to what a good thing it is to get connected to an efficient distribution system and an efficient milling system. [The other farmer] is the first one to say that he doesn't mill on a scale large enough to really be priced competitively. [His flour] falls into more of the category of a specialty flour.

The mill consultant (Interviewee 1) pointed out the implications of scale when it comes to a product such as flour that is blended to achieve consistent quality:

The other issue is consistency. The larger mills, they can do in a couple of days what we're doing... but their flour is consistent around the year. They are carefully testing every wheat that they buy and they put blends together so that the flour they're milling this week is like the flour that they are going to be milling the third week of December, which is the same as what they'll be milling in May. And that's a tough thing for small mills to do.

Interviewee 1 pointed out that with a local wheat system as small as his, quality between batches is actually more consistent than buying blended flour:

The mill that we buy from in Kansas is a small organic mill that is quite connected to their farmers and doesn't have the ability to blend and get absolutely the same result from lot to lot so we're quite used to paying attention to changes. So in reality, making breads with the local wheat in the two years that we've been doing it has actually been easier because you're dealing with one crop year [from the same two farms] for the entire year. The type of adjustment we made once a year was equivalent to the adjustment we do every couple of weeks with the wheat that's coming out of Kansas.

Just as the scale of the supplier has a great effect on quality of the product, the scale of the bakery has an effect on quality tolerances, as stated by Interviewee 1: "Someone who is baking three dozen loaves and is selling at the farmers market can afford to have different criteria [for quality] than someone who is selling at the Whole Foods store."

\section{Discussion}

There are important differences to consider between grains and fresh foods that present both challenges and opportunities for the incorporation of grains such as wheat into a local food system. Wheat is usually consumed in a processed form and typically undergoes some level of blending during the milling process to achieve the desired end-use qualities in the resulting flour. It is used frequently in multi-ingredient products and often is not used as a "center of plate ingredient" (HomeGrown Cereals Authority, 2009). Because of their relatively low water content, grains and flour typically have a longer shelf life than some other types of food products; hence "freshness" is not usually as much of a concern for a bag of white flour compared to a cut of steak or a head of lettuce. Freshness can be important when it comes to whole-grain flour, as fresh-milled flour is known to have improved flavor. Local milling of flour presents an opportunity to add value to wheat grown in the region.

Another difference is that the price a producer receives for his or her wheat in the U.S. is set by a board of exchange and does not necessarily reflect the cost of production. Factors affecting the price of wheat are global in nature and include weather conditions in other wheat-producing countries, politics, and price speculation. It is unclear to what extent those growing wheat for local markets can detach from global wheat prices.

The Home-Grown Cereals Authority (HGCA), the organization responsible for use of cereals and oilseed levies in the United Kingdom, produced a report titled "Provenance in the Cereals Sector" (HGCA, 2009). The authors found that for provenance (the method or tradition of production that is attributable to local influences) to become a more widespread factor in cereal products, there will need to be a change in the way these products are viewed. Flour is currently viewed as a massproduced product. Brands are viewed as the quality indicator because consumers find it difficult to compare quality differences across flour. 


\section{Challenges}

Grains have different infrastructure requirements than fresh produce in terms of production, storage, and processing. The grain sector is among the most highly consolidated sectors in the global food system, with five major companies (Cargill, Archer Daniels Midland, Bunge, Louis Dreyfus Commodities, and ConAgra) controlling 80 percent of the global grain trade (Measner, 2007). The level of consolidation in the grain processing industry is so high that a Kansas baker may find it difficult to source local whole-wheat flour (Henning, 2011). This may explain the minimal role that grains have played in the local foods market so far.

Mount (2012) posits that farmers who produce commodities that require processing will be challenged to access the added value that comes from eliminating profit-taking intermediaries. Alternatively, these farmers could become part of vertically integrated food value chains by doing their own milling and by marketing the flour, allowing them to capture the added value.

Given the challenges in the development of a local wheat-flour supply chain, it may be more realistic for supply-chain intermediaries to encourage bakers to incorporate a percentage of local flour along with their conventionally supplied flour. This could be seen as an intermediate step that would allow bakers to support the development of a western Washington wheat-flour supply chain without taking the risk of using 100 percent western Washington flour. This supply chain will have an improved ability to control quality as it matures due to the inclusion of more producers and the education of these producers about which varieties and agronomic practices will ensure good baking quality.

A question that was beyond the scope of the survey but could be important for the local wheat market is whether bakers and their customers would be willing to pay a price premium for a blended product (for example, 50 percent western Washington wheat and 50 percent other wheat). Very little is available in the academic literature about willingness to pay for blended local products. Batte, Hooker, Haab, and Beaverson (2007) found that Ohio consumers were willing to pay a price premium for multi-ingredient processed foods with less than 100 percent organic ingredients. When asked about a variety of characteristics that might command a price premium in the supermarket, respondents had a mean willingness to pay a premium of $\$ 0.42$ for a box of breakfast cereal with 100 percent local ingredients that would normally be $\$ 3.00$ for a conventional product. It is unclear whether similar results would occur for products that contained less than 100 percent local ingredients.

Because it is not feasible for consumers to keep track of the origin of every ingredient in baked products they purchase, it is likely that they will put trust in a baker to source ingredients produced in a sustainable manner. One part of this sustainability may include where the wheat was produced and processed. This is similar to the way that direct-market customers of non-certified organic farms put trust in the grower to make sustainable choices in the way that he or she manages the farm, rather than requiring that they adhere to a strict set of standards, such as the National Organic Program. Especially important in the case of processed or multi-ingredient products is the trust that one intermediary puts in another intermediary in the food chain downstream of the producer, such as between retailers and processors (Dunne et al., 2010) or, in the case of wheat flour, between bakers and flour processor (miller).

The obstacles to purchasing local wheat mentioned by survey respondents were similar to those identified by Painter (2008) related to restaurant purchases, including inconsistent availability and quality, difficulty identifying reliable local suppliers, difficulty in making purchases (due to farmers' ordering procedures), and the inconvenience of dealing with multiple suppliers. In the current industrial food system, it is much easier for businesses to source material from one or two distributors that can reliably ensure access than to work with many small suppliers. Local grain movements may benefit from the experiences of restaurants using local foods, many of which have successfully overcome similar obstacles.

\section{Opportunities}

While challenges exist for relocalizing wheat production, opportunities also exist in the local 
grain sector. One major opportunity to add value is through identity preservation, or maintaining information about where the grain is grown and by whom, throughout the supply chain. According to the HGCA (2009), cereal products are responsible for a relatively small percentage of the total shopping bill, making consumers less likely to compare price than they would with other, higher priced items on their shopping list. Because there has been little focus on origin in the grain sector, "producers, processors and manufacturers have a blank canvas to develop an association between their region and cereal products and fill the local food 'gap'. This is relevant to both artisan/small scale producers and larger scale producers that can emphasize their links to a specific region" (HGCA, 2009 , p. 5). Also, their ability to be stored allows local grains to be available year-round, filling in the seasonal gaps in local fresh produce. The opportunity to produce gluten-free grains for the burgeoning market for gluten-free baked goods in the U.S may offer a niche market for growers of some types of grains.

While we anticipated that bakers focusing on bread might be the most interested in local flours, survey respondents' level of interest in local wheat flour was not related to the percentage of their sales from bread. This may indicate an opportunity to market local wheat flour for use in pastries, pita bread, cakes, cookies, or other products that have different quality parameters from those required for bread production. Grocery store bakeries and large national chains were not included in this survey but may offer additional markets for local wheat.

\section{Conclusion}

The results of this study can inform grain relocalization efforts by revealing the inherent challenges and opportunities in connecting staple crop (e.g., wheat) producers, supply-chain intermediaries (e.g., processors and bakers), and consumers. Our results also contribute to the nascent literatures on the relocalization of staple crops (see, e.g., Giombolini, Chambers, Bowersox, \& Henry, 2011) and the perspectives of supply-chain intermediaries.

Most commercial bakers who responded to our survey defined local as either in the state of
Washington or in a multistate region. Fourteen percent of respondents gave reflexive definitions of local, reflecting the complexities of food systems in general and wheat-flour supply chains in particular. Location-specific factors such as climate and land value, as well as respondents' knowledge of the regional production of crops, may have contributed to the level of flexible localism expressed by respondents. There are also indications that commercial bakers' definitions of local are highly influenced by factors such as availability of product. There may be differences in the way that commercial bakers define local for wheat/flour as opposed to other types of ingredients. The expression of flexible localism in this study was similar to Morris and Buller's (2003) study of local food retailers and Milestad et al.'s (2010) study of actors in the cereal supply chain, though flexible localism was not quantitatively measured in these studies.

We found that definitions of local varied widely among commercial bakers in western Washington, similar to Dunne et al.'s (2010) finding among food retailers in Oregon. The bakers' definitions were often based on political boundaries, but also included definitions based on miles or driving time. It is likely that in defining local, supply-chain intermediaries may take factors such as the existence of processing infrastructure and distribution into account more than producers or consumers would. Our results supported those of Milestad et al. (2010), in which actors in an organic cereal and bread supply chain in Austria expressed flexible localism based on location of inputs and consumers. In Dunne et al. (2010), transportation systems were mentioned as a factor among food retailers in Oregon when proposing a definition of local. While questions about transportation were not included in our survey, distribution was cited by survey respondents as one of the barriers to the use of regionally produced wheat/flour.

Dunne et al. (2010) found that smaller retailers used smaller spatial boundaries for defining local. In contrast, our study found that bakers distributing within smaller spatial boundaries (i.e., their county) were likely to define local using larger boundaries. This may be due to the differences in sourcing and distribution systems between bakeries and food retailers such as grocery stores. 
Similar opportunities and challenges exist in the relocalization of staple crops (e.g., grain) as exist for other local food systems. Reestablishment of what Hergesheimer and Wittman (2012) refer to as "place-based grain systems" in locations that historically grew their own grain has the potential to increase crop diversity and improve farm profitability, resulting in the preservation of farmland. The barriers related to lack of infrastructure and cost-effective processing and distribution pose challenges for the development of local grain supply chains, much as they have for local food supply chains as identified by Starr et al. (2003), Inwood et al. (2009), and Vogt and Kaiser (2008). As with other types of food, economies of scale in a local grain system can be difficult to achieve without the product volumes to access the mainstream supply chain. One strategy for dealing with this could be vertical integration, in which growers incorporate processing (or even baking) into their businesses. Through brand identification and consumer trust, commercial bakers could play a key role in the relocalization of wheat.

Research on the process of relocalization is still in its early stages (Sonnino \& Marsden, 2006), but studies of food chain intermediaries (e.g., commercial bakers) have the opportunity to provide insight into relocalization efforts, especially for staple crops, which have been underrepresented in the local foods movement despite their importance in human diets. The staple crop relocalization movement is still evolving in western Washington and other regions. Answers to remaining questions may become clear as local grain movements involving bakers and growers work on parallel fronts to shorten supply chains in ways that are beneficial for businesses, communities, and consumers, to reaffirm the connection between producers and consumers of staple crops, and to transform grains from an anonymous interchangeable commodity to a food grown on a farm by a farmer to provide human sustenance.

\section{Acknowledgements}

The authors would like to acknowledge the following individuals and organization for their assistance with this project: Carol Miles, Andrew Corbin, Steve Lyon, Andrew Ross, Jurgen Bettag, Jo
Ferneau, Sheila Carder, Garrett Furuichi, Lucas

Patzek, and the Bread Bakers Guild of America.

\section{References}

American Farmland Trust. (2012). Western Washington Foodshed Study: The Project. Retrieved August 1, 2012, from http://wafoodshed.wix.com/western-wafoodshed

Appalachian Staple Food Cooperative. (n.d.). Home. Retrieved April 28, 2012, from http://asfc.weebly.com

Bassetti, G., \& Galton, J. (1998). Cooking with artisan bread. Seattle: Sasquatch Books.

Batte, M. T., Hooker, N. H., Haab, T. C., \& Beaverson, J. (2007). Putting their money where their mouths are: Consumer willingness to pay for multiingredient, processed organic food products. Food Policy, 32(2), 145-149. http://dx.doi.org/10.1016/i.foodpol.2006.05.003

Bloom, J. D., \& Hinrichs, C. C. (2010). Moving local food through conventional food system infrastructure: Value chain framework comparisons and insights. Renewable Agriculture and Food Systems, 26(1), 13-23. http://dx.doi.org/10.1017/S1742170510000384

Brady, M., \& Taylor, J. (2011). Agriculture's contribution to Washington's economy [IMPACT Center Fact Sheet]. Pullman, Washington: Washington State University.

Cantrell, C., \& Lewis, R. (2010). Food system infrastructure: Michigan Good Food Work Group Report Series [Report No. 5 of 5]. East Lansing, Michigan: C. S. Mott Group for Sustainable Food Systems at Michigan State University. http://www.michiganfood.org/assets/goodfood/ docs/Food System Infrastructure Report.pdf

Carolan, M. (2011). The real cost of cheap food. London: Earthscan.

Compendium of Washington Agriculture. (2011). WSCPR The Compendium of Washington Agriculture Online. Retrieved from http:// 69.93.14.225/wscpr/WSCPRBook.cfm

DeLind, L. B. (2011). Are local food and the local food movement taking us where we want to go? Or are we hitching out wagons to the wrong stars? Agriculture and Human Values, 28(2), 273-283. http://dx.doi.org/10.1007/s10460-010-9263-0

Dillman, D. A., Smyth, J. D., \& Christian, L. M. (2009). Internet, mail, and mixed-mode surveys: The tailored design method. Third Edition. Hoboken, New Jersey: John Wiley and Sons. 
Dunne, J. B., Chambers, K. J., Giombolini, K. J., \& Schlegel, S A. (2010). What does 'local' mean in the grocery store? Multiplicity in food retailers' perspectives on sourcing and marketing local foods. Renewable Agriculture and Food Systems, 26(1), 46-59. http://dx.doi.org/10.1017/S1742170510000402

Feenstra, G. W. (1997). Local food systems and sustainable communities. American Journal of Alternative Agriculture, 12(1), 28-36. http://dx.doi.org/10.1017/S0889189300007165

Fonte, M. (2008). Knowledge, food and place. A way of producing, a way of knowing. Sociologia Ruralis, 48(3), 200-222. http://dx.doi.org/10.1111/j.14679523.2008.00462.x

Giombolini, K. J., Chambers, K. J., Bowersox, J. W., \& Henry, P. M. (2011). From turf to table: Grass seed to edible grains in the Willamette Valley. Journal of Agriculture, Food Systems, and Community Development, 2(1), 141-162. http://dx.doi.org/10.5304/jafscd.2011.021.008

Giovannucci, D., Barham, E., \& Pirog, R. (2010). Defining and marketing "local" foods: Geographical indications for US products. The Journal of World Intellectual Property, 13(2), 94-120. http://dx.doi.org/10.1111/j.1747-1796.2009. 00370.x

Hanus, J. (2010, March 5). Want food security? Start seeing staples [Web log posting]. Utne Reader. Retrieved from http://www.utne.com/The-SweetPursuit/Want-Food-Security-Start-Seeing-Staples6810.aspx

Heffernan, W., Hendrickson, M., \& Gronski, R. (1999). Consolidation in the food and agriculture system [Report to the National Farmers Union]. Washington, D.C.: National Farmers Union. Retrieved from http://www.foodcircles.missouri.edu/whstudy.pdf

Henning, S. (2011, June 14). Doughnut hole: Ban highlights difficulties of getting local flour in the Wheat State. Lawrence Journal-World. http://www2.ljworld.com/news/2011/jun/14/ doughnut-hole-ban-highlights-difficulties-getting-/

Hergesheimer, C., \& Wittman, H. (2012). Weaving chains of grain: Alternative grain networks and social value in British Columbia. Food, Culture and Society, 15(3), 375-393.
Hills, K., Corbin, A., \& Jones, S. (2011). Rebuilding the grain chain: Stories from the coastal Pacific Northwest. Rural Connections, 6(1), 31-36.

Hills, K. M., Goldberger, J. R., \& Jones, S. S. (2013). Commercial bakers and the relocalization of wheat in western Washington State. Agriculture and Human Values, 30(3), 365-378. http://dx.doi.org/10.1007/s10460-012-9403-9

Hills, K., \& Jones, S. (2012). Local grain production in the Skagit Valley. Bread Lines (Bread Bakers Guild of America), 20(1), 36-38.

Home-Grown Cereals Authority (HGCA). (2009). Provenance in the cereals sector. http://www.hgca.com/publications/documents/ HGCA-Provenance.pdf

Ilbery, B., \& Maye, D. (2005). Food supply chains and sustainability: Evidence from specialist food producers in the Scottish/English borders. Land Use Policy, 22(4), 331-344. http://dx.doi.org/ 10.1016/j.landusepol.2004.06.002

Ilbery, B., \& Maye, D. (2006). Retailing food in the Scottish- English borders: A supply chain perspective. Geoforum, 37(3), 352-367. http://dx.doi.org/10.1016/j.geoforum.2005.09.003

Inwood, S. M., Sharp, J. S., Moore, R. H., \& Stinner, D. H. (2009). Restaurants, chefs and local foods: Insights drawn from application of a diffusion of innovation framework. Agriculture and Human Values, 26(3), 177-191. http://dx.doi.org/10.1007/s10460-008-9165-6

Kavage, S. (n.d.). Industrial harvest. www.industrialharvest.com

King, R. P., Gómez, M. I., \& DiGiacomo. G. (2010). Can local food go mainstream? Choices, 25(1). http://www.choicesmagazine.org/magazine/ article.php?article $=111$

Kingsolver, B., Hopp, S. L., \& Kingsolver, C. (2007). Animal, vegetable, miracle: A year of food life. New York: HarperCollins Publishers.

Low, S. A., \& Vogel, S. (2011). Direct and intermediated marketing of local foods in the United States [ERR-128]. Washington, D.C.: United States Department of Agriculture-Economic Research Service.

Lyson, T. A. (2004). Civic agriculture: Reconnecting farm, food and community. Medford, Massachusetts: Tufts University Press. 
Martinez, S., Hand, M. S., Da Pra, M., Pollack, S., Ralston, K., Smith, T.,...Newman, C. (2010). Local food systems: Concepts, impacts, and issues [ERR-97]. Washington, D.C.: United States Department of Agriculture-Economic Research Service. http://www.ers.usda.gov/publications/erreconomic-research-report/err97.aspx

McClintock, N. (2010). Why farm the city? Theorizing urban agriculture through a lens of metabolic rift. Cambridge Journal of Regions, Economy and Society, 3(2), 191-207. http://dx.doi.org/10.1093/cjres/rsq005

Measner, A. (2007). The global grain trade and the Canadian Wheat Board. In T. Pugh and D. McLaughlin (Eds.), Our board our business: Why farmers support the Canadian Wheat Board (pp. 30-41). Halifax: Fernwood Publishing.

Milestad, R., Bartel-Kratochvil, R., Leitner, H., \& Axmann, P. (2010). Being close: The quality of social relationships in a local organic cereal and bread network in Lower Austria. Journal of Rural Studies, 26(3), 228-240. http://dx.doi.org/10.1016/j.jrurstud.2010.01.004

Mitchell, D. O., \& Mielke, M. (2005). Wheat: The global market, policies, and priorities. In M. A. Aksoy, \& J. C. Beghin (Eds.), Global agricultural trade and developing countries (pp. 195-214). Washington, D.C.: The World Bank.

Morris, C., \& Buller, H. (2003). The local food sector: A preliminary assessment of its form and impact in Gloucestershire. British Food Journal, 105(8), 559-566. http://dx.doi.org/10.1108/00070700310497318

Mount, P. (2012). Growing local food: Scale and local food systems governance. Agriculture and Human Values, 29(1), 107-121. http://dx.doi.org/10.1007/s10460-011-9331-0

Ostrom, M. (2006). Everyday meanings of "local food": Views from home and field. Community Development, 37(1), 65-78. http://dx.doi.org/10.1080/15575330609490155

Painter, K. (2008). An analysis of food-chain demand for differentiated farm commodities: Implications for farm sector [Rural Business and Cooperative Programs Research Report 215]. Washington, D.C.: United States Department of Agriculture-Rural Development. http://www.rurdev.usda.gov/ RBS/pub/Painter Report Small.pdf
Patzek, L. (2012). Impacts of nitrogen fertility, soilborne disease, and socioeconomic factors on diverse small grain production systems of the Pacific Northwest (Doctoral dissertation). Washington State University, Pullman, Washington.

Peters, C. J., Bills, N. L., Lembo, A. J., Wilkins, J. L., \& Fick, G. W. (2009). Mapping potential foodsheds in New York State: A spatial model for evaluating the capacity to localize food production. Renewable Agriculture and Food Systems, 24(1), 72-84. http://dx.doi.org/10.1017/S1742170508002457

Pirog, R., \& Rasmussen, R. (2008). Food, fuel and the future: Consumer perceptions of local food, food safety and climate change in the context of rising prices. Leopold Center for Sustainable Agriculture. Retrieved from http://www.leopold.iastate.edu/sites/default/files/ pubs-and-papers /2008-09-food-fuel-and-futureconsumer-perceptions-local-food-food-safety-andclimate-change-context-rising-p.pdf

Pollan, M. (2006). The omnivore's dilemma: A natural history of four meals. New York: Penguin Press.

Qazi, J. A., \& Selfa, T. L. (2005). The politics of building agro-food networks in the belly of agro-industry. Food, Culture and Society, 8(1), 45-72. http://dx.doi.org/10.2752/155280105778055416

Schnell, S. M. (2013). Food miles, local eating, and community supported agriculture: Putting local food in its place. Agriculture and Human Values. http://dx.doi.org/10.1007/s10460-013-9436-8

Selfa, T., \& Qazi, J. (2005). Place, taste, or face-to-face? Understanding producer-consumer networks in "local" food systems in Washington State. Agriculture and Human Values, 22(4), 451-464. http://dx.doi.org/10.1007/s10460-005-3401-0

Severson, K. (2009, May 13). When 'local' makes it big. The New York Times, p. D1.

Sonnino, R., \& Marsden, T. (2006). Beyond the divide: Rethinking relationships between alternative and conventional food networks in Europe. Journal of Economic Geography, 6(2), 181-199. http://dx.doi.org/10.1093/jeg/lbi006

Starr, A., Card, A., Bnepe, C., Auld, G., Lamm, D., Smith, K., \& Wilken, K. (2003). Sustaining local agriculture: Barriers and opportunities to direct marketing between farms and restaurants in Colorado. Agriculture and Human Values, 20(3), 301321. http://dx.doi.org/10.1023/A:1026169122326 
Stevenson, S. (2009). V alues-based food supply chains: Shepherd's Grain. Retrieved from the Agriculture of the Middle website: http://www.agofthemiddle. org/pubs/sgcasestudyfinalrev.pdf

Suas, M. (2009). Advanced bread and pastry: A professional approach. Clifton, New York: Delmar Cengage Learning.

Thilmany, J. (2010, November 1). The future of grains [Web log post]. Baking Management. http://bakingmanagement.com/ingredients/updated-dietaryguidelines-1110/

Tregear, A. (2011). Progressing knowledge in alternative and local food networks: Critical reflections and a research agenda. Journal of Rural Studies, 27(4), 419-430. http://dx.doi.org/10.1016/j.jrurstud.2011.06.003

U.S. Department of Agriculture (USDA). (n.d.). Know Your Farmer, Know Your Food. Retrieved July 11, 2012, from http://www.usda.gov/wps/portal/ usda/usdahome?navid=KYF COMPASS

USDA-Economic Research Service (USDA-ERS). (2009). Food availability — Grains. Retrieved from http://www.ers.usda.gov/Data/FoodConsumption $\angle$ FoodAvailSpreadsheets.htm\#grains

USDA-Foreign Agricultural Service (USDA-FAS). (2011, October). World agricultural production [Circular Series WAP 10-11]. Retrieved from www.fas.usda.gov/wap_arc.asp
USDA-National Agricultural Statistics Service (USDANASS). (2007). State agricultural overview. Retrieved from http://www.nass.usda.gov/

Ver Ploeg, M., Breneman, V., Farrigan, T., Hamrick, K., Hopkins, D., Kaufman, P.,...Tuckermanty, E. (2009). Access to affordable and nutritious food: Measuring and understanding food deserts and their consequences

[Report AP-036]. Washington, D.C.: United States Department of Agriculture-Economic Research Service. Retrieved from http://www.ers.usda.gov/ publications/ap-administrative-publication/ ap-036.aspx

Vogt, R. A., \& Kaiser, L. L. (2008). Still a time to act: A review of institutional marketing of regionallygrown food. Agriculture and Human Values, 25(2), 241-255. http://dx.doi.org/10.1007/s10460-0079106-9

Washington Grain Alliance. (2010). All about wheat. Retrieved January 30, 2012, from http://www.wawg.org/consumers.html

Whitaker, S. (2007). Prodigious success. Milling and Baking News, March 13, 19-20, 22-24.

Wolfe, T. M. (2011, April 1). The North Carolina organic bread flour project. The Laurel of Asheville. http://thelaurelofasheville.com/issues/2011/04/ the-nc-organic-bread-flour-project 